\title{
Detection of Pathogenic Bacteria and Heavy Metal on Liquid Organic Fertilizer from Dairy Cattle Waste
}

\author{
Marlina ET, Kurnani TBA, Hidayati YA, Badruzzaman DZ, Firman A \\ Faculty of Animal Husbandry, Padjadjaran University \\ Jl. Raya Bandung Sumedang Km 21, Jatinangor 45363, West Java, Indonesia \\ marlinalistanti@gmail.com; eulis.tanti@unpad.ac.id
}

\begin{abstract}
Dairy cattle waste has positive potential that can be explored to be useful product, the negative property of waste should be controlled to avoid environmental pollution. Dairy cattle waste can be processed into liquid organic fertilizer for crops. The aim of study was to determine the number of pathogenic bacteria (Escherichia coli and Salmonella sp.) as well as heavy metals ( $\mathrm{Pb}, \mathrm{Cd}, \mathrm{As}, \mathrm{Hg}$ ) in liquid organic fertilizer from dairy cattle waste. Liquid organic fertilizer is obtained by extracting the decomposition substrate from dairy cattle waste and rice straw with water solvent. The study was conducted experimentally using a completely randomized design with three treatments namely ratio decomposers to waters and 6 replications. Data were analyzed by analysis of variance and Duncan test to determine the difference between treatments. The result showed that: (1) the content of both Escherichia coli and Salmonella sp. are <30 MPN/ml; (2) the highest level of heavy metals $\mathrm{Pb}, \mathrm{Cd}$, and As are 0,17 ppm, 0,1 ppm, and 0,3 ppm respectively, while $\mathrm{Hg}$ is not detected in all treatments. Either pathogenic bacteria or heavy metals accounted below recommendation limit in the minimum technical requirement by Permentan number 70/Permentan/SR/140/10/2011.
\end{abstract}

Key Words: Pathogenic Bacteria, Heavy Metals, Dairy Cattle Waste, Liquid Organic Fertilizer

\section{INTRODUCTION}

In order to improve the production performance of dairy cows in the peri-urban farms, one of the problems that must be managed is environmental pollution caused by waste. Cattle feces that is not managed properly can have a negative effect on people's lives. Disposal of waste into water bodies directly or indirectly will affect water pollution, and as a result water quality is decreasing. Moreover, the polluted river will also potentially be a source of disease that we often refer as "waterborn disease" affecting the degradation of public health in surrounding areas.

Dairy farm waste has several characteristics that contribute to environmental sanitation, the $\mathrm{C} / \mathrm{N}$ ratio, $\mathrm{BOD}$ and the high number of pathogenic microbes. Therefore, the management of environmental sanitation can be managed through the processing of farm waste into products that do not directly enter into the environmental and have an economic value, such as liquid organic fertilizer. The process to utilize waste into liquid organic fertilizer is an effort to reduce the number of pathogenic bacteria (Escherichia coli and Salmonella sp.) on farm waste to become safe in the environment.

Pathogenic microorganisms have access to their host through gastrointestinal tract (e.g. enteric viruses and bacteria), through the respiratory tract (e.g. Klebsiella pneumoniae, legionella, and myxovirus), or it can be through the skin (e.g. Aeromonas, Clostridium tetani, and Clostridium perfringens). Some pathogenic microorganisms and parasites are usually found in waste water. Several diseases caused by infectious agents that are often found in waste water, among other bacterial pathogens, such as Salmonella, Vibrio cholerae, E. coli, Yersinia, Campylobacter, Leptospira, L. pneumophila, etc. 
Animal feces containing more than $10^{12}$ bacteria per gram. The content of the bacteria in the feces was approximately $9 \%$ of wet weight (Dean \& Lund in Gray 2008).

Salmonella sp. is Enterobacteriaceae which widely distributed in the environment, and covers more than 2,000 stereotypes. Salmonella is the most important bacterial pathogens present in the waste water, which can cause typhoid and paratyphoid fever, and gastroenteristis. Salmonella concentration in wastewater accounted for a few cells to 8000 organisms per $100 \mathrm{ml}$ of wastewater (Feachem et al. 1983). Salmonella typhii is the infectious agent of typhoid fever, a disease that if not promptly treated can cause death. Salmonella typhii produce endotoxins that can cause fever, nausea, and diarrhea, and can be fatal if not treated with antibiotics. (Sterrit \& Lester 1988). Species Salmonella typhimurium and $S$. Enteritidis can cause gastroenteritis.

In the gastrointestinal of humans and warm-blooded animals, there are several strains of $E$. coli which are harmless while the other can release toxins that cause diarrhea. Some strains of $E$. coli that are enterotoxigenic (ETEC), enteropathogenic (EPEC), enterohemooragic (EHEC), and enteroinvasive (Levine 1987). Enterotoxigenic E. coli can cause inflammation of the stomach (gastroenteritis) and severe diarrhea accompanied by abdominal cramps and vomiting (Harris 1986). Approximately 2-8\% of E. coli present in the water are enteropathogenic that can cause diarrhea. Water and food are factors of infection and spread of the E. coli.

Heavy metals are metals with high molecular weight. Even in low concentrations, heavy metals generally are toxic for plants and animals, including humans, some types of heavy metals which often cause pollution are Mercury $(\mathrm{Hg})$, Chromium $(\mathrm{Cr})$, Cadmium $(\mathrm{Cd})$, lead $(\mathrm{Pb})$ and Arsenic (As). Presence of heavy metals in the environment can not in themselves harmful to living things, including humans. Heavy metals can be dangerous when entered into the metabolic system in an amount which exceeds the threshold (Alloway 1995; Lacatusu 2000; Moenir et al. 2010).

The content of $\mathrm{Cd}$ in Phosphate fertilizers can be found in the range of 1.94 to 113 $\mathrm{mg} / \mathrm{kg}$ of fertilizer in some countries. Natural Phosphate from Senegal-Africa contain Cadmium relatively higher than in other countries and generally the phosphate rock, raw material for $\mathrm{P}$ fertilizers, contain Cadmium $<500 \mathrm{mg} / \mathrm{kg}$ (Alloway 1995). This implies that the quality of the natural Phosphate strongly influenced by the type and origin of raw materials phosphate rock.

Beside fertilizer as source of inorganic phosphate, organic fertilizer derived from manure, compost and lime contain heavy metals in significant amounts. $\mathrm{Cd}$ content of inorganic phosphate fertilizer and compost is quite high, compared to other fertilizers. The level of $\mathrm{Cd}$ accumulated in the soil depends on the levels of cadmium in fertilizers and fertilizer dose given. Manure from chicken and cow also contains $\mathrm{Cd}$ in an amount of more than $50 \mathrm{mg} / \mathrm{kg}$ (Laegreid et al. 1999).

This research will analyze the content of pathogenic bacteria (Escherichia coli and Salmonella sp.) and heavy metals $(\mathrm{Pb}, \mathrm{Cd}, \mathrm{As}, \mathrm{Hg})$ in a liquid organic fertilizer produced from dairy cattle waste.

\section{MATERIAL AND METHODS}

\section{Sample collection and preparation}

Dairy cattle waste was collected gradually until sufficient as research material, and then mixed with rice straw that comes from farms in Jatinangor Region Sumedang. To obtained C/N ratio 30, the comparison of dairy cattle waste and rice straw was 25:75. 


\section{Pre-composting}

A mixture of dairy cattle waste and rice straw is placed into a sack and closed. Subsequently the mixture was incubated aerobically for 7 days, until decomposing microorganisms such as fungi and bacteria grow. After the incubation process is completed, aerated to reduce the water content until it reaches $30 \%$. The results of this process called "decomposers".

\section{Extraction process}

The extraction process of decomposers is using hot water (temperature $\pm 90^{\circ} \mathrm{C}$ ) with a ratio according to treatment: $1 \mathrm{~kg}$ of decomposers in 4 liters of water (T1); $1 \mathrm{~kg}$ of decomposers in 6 liters of water (T2); $1 \mathrm{~kg}$ of decomposers in 8 liters of water (T3). The filtrate extraction is incubated for 2 weeks, while doing aeration every day for 30 minutes to accelerate the fermentation process.

\section{Bacterial culture preparation}

Testing the amount of E. coli and Salmonella utilized MPN method-Durham and further test on McConkey media and Salmonella shigella Agar (SSA) (Kementan 2011).

\section{RESULTS AND DISCUSSION}

Temperature is an indicator of the activity of microorganisms in the composting process. Microorganisms perform the decomposition of organic material into simpler compounds. Therefore, the composting process before the process incomplete is called the early decomposition process. Changes in temperature during the early decomposition process are presented in Figure 1.

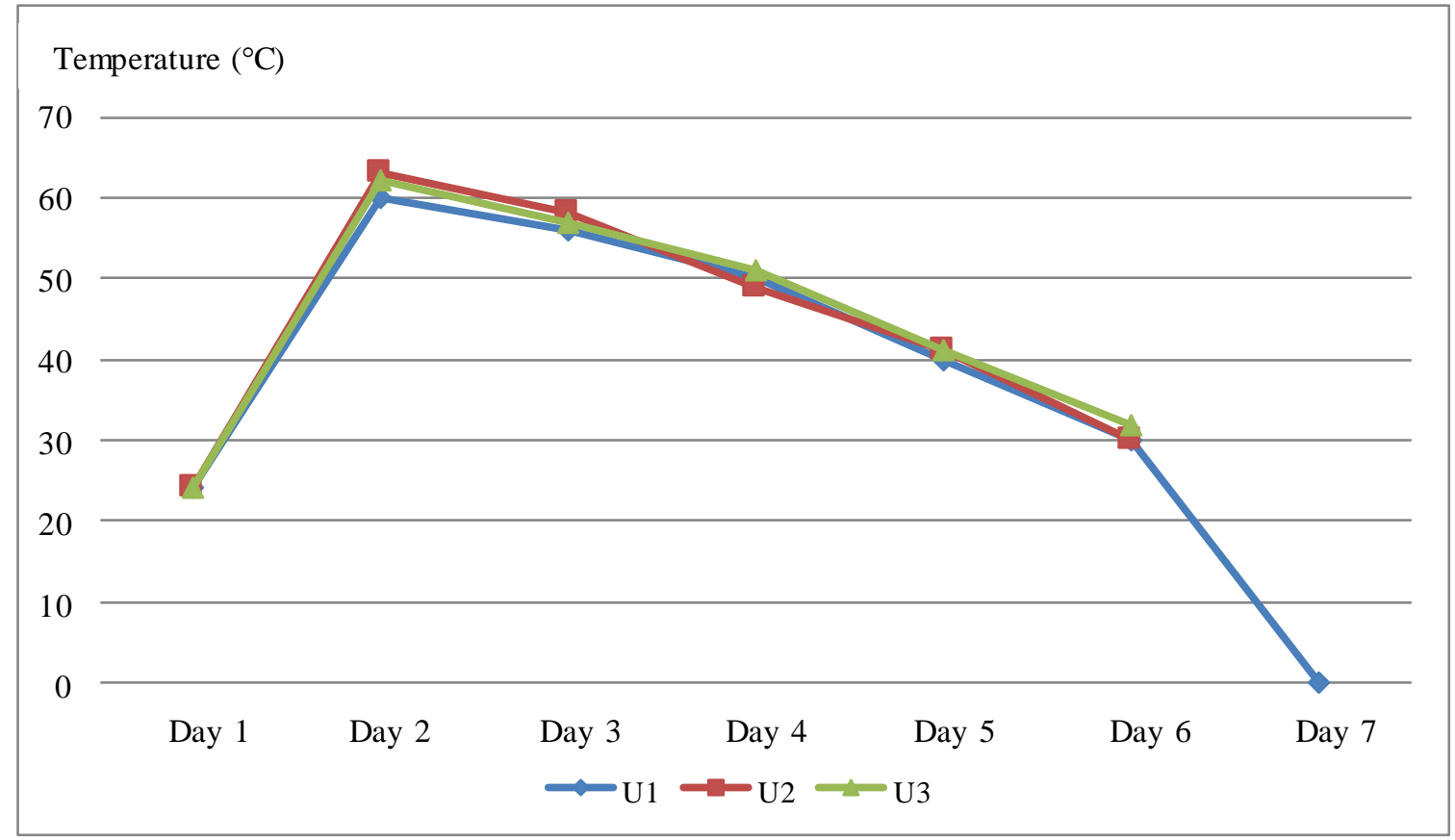

Figure 1. Changes in temperature $\left({ }^{\circ} \mathrm{C}\right)$ during the early decomposition process 
Temperature is measured every day in order to indicate how well the decomposition process is. Temperature is the main factor affecting microorganisms activity in decomposing organic matter (Epstein 1997). During the decomposition, the highest temperature occurred on second day, which ranged between $60-63^{\circ} \mathrm{C}$. After that, temperature decreased continuously until it reaches the ambient temperature $24-25^{\circ} \mathrm{C}$. Controlling the temperature during the decomposition process is necessary to optimize microbial growth and reduce pathogenic bacteria (Pholprasert 1989; Benito et al. 2010; Marlina et al. 2008). The optimal early decomposition produces microbial biomass that serves as a nutrient for liquid organic fertilizer materials on the advanced integrated waste treatment process.

The nutrient availability for microorganisms needs is reflected by the balance between carbon and nitrogen or $\mathrm{C} / \mathrm{N}$ ratio. $\mathrm{C} / \mathrm{N}$ ratio at the beginning of the early decomposition was set at 30. During the decomposition process occurs degradation of carbon and nitrogen is used as a source of nutrients for microorganisms decomposers.

Table 1.Total pathogenic bacteria and heavy metal in organic liquid fertilizer from dairy cattle waste

\begin{tabular}{lcccc}
\hline \hline Parameter & Unit & $\mathrm{T}_{1}$ & $\mathrm{~T}_{2}$ & $\mathrm{~T}_{3}$ \\
\hline Escherichiacoli & $\mathrm{MPN} / \mathrm{ml}$ & $<30$ & $<30$ & $<30$ \\
Salmonella sp. & $\mathrm{MPN} / \mathrm{ml}$ & $<30$ & $<30$ & $<30$ \\
$\mathrm{~Pb}$ & $\mathrm{ppm}$ & 0.17 & 0.20 & 0.17 \\
$\mathrm{Cd}$ & $\mathrm{ppm}$ & 0.10 & 0.10 & 0.10 \\
$\mathrm{As}$ & $\mathrm{ppm}$ & 0.15 & 0.10 & 0.30 \\
$\mathrm{Hg}$ & $\mathrm{ppm}$ & 0.00 & 0.00 & 0.00 \\
\hline
\end{tabular}

$\mathrm{T}_{1}=1: 4 ; \mathrm{T}_{2}=1: 6 ; \mathrm{T}_{3}=1: 8$

Livestock waste treatment through aerobic fermentation is able to reduce pathogenic bacteria, so that the organic fertilizer produced will not contaminate groundwater when applied to plant (Marlina et al. 2008; Benito et al. 2010). The bacteria found in cattle feces are Escherichia coli and Salmonella sp., a group of bacteria enterobacteriaceae. This group of bacteria exist in large numbers in the faeces of humans and animals and in contaminated water, but not in pure water, soil and environment that were not exposed by feces of animals and humans. These groups of bacteria do not multiply in the environment (Ashbolt et al. 2001). E. coli is an indicator bacterium of environmental sanitation, so its presence in water indicates that the water has been contaminated by feces (Ashbolt et al. 2001; Jay et al. 2005). During early decomposition the number of E. coli and Salmonella sp. decrease. Increasing temperature during the decomposition is the result of an degradation of organic material on the substrate. This is in line with the opinion of Dalzell et al. (1987) that the amount of energy is released in the form of heat directly to the degradation of organic material. This resulted in a rise in temperature in the pile decomposers. The ideal temperature of the composting is in thermophilic because at these temperatures occur active decomposition of organic material (Marlina et al. 2008). By using oxygen, compost microbes will decompose organic matter into $\mathrm{CO}_{2}$, water vapor and heat. The bacteria cannot stand the heat, including Enterobacteriaceae group will die.

Heavy metals is one of parameters indicating whether or not compost fit for organic fertilizer. If heavy metals have been absorbed into the body, it can not be destroyed but would have stayed until removed through excretion (Nordberg et al. 1986). Similarly, when an environment, especially in waters have been contaminated (polluted) by heavy 
metals then the cleanup process will be very difficult to do. Heavy metals contamination can occur when fertilizer is applied to the plants contained heavy metals that exceed recommendation limit. Therefore some organic fertilizer require heavy metals as a parameter of eligibility. However, the material for composting of dairy cattle feces and rice straw, containing heavy metals below the required threshold. Standard quality requirement of organic fertilizer for heavy metal content in organic fertilizers are lead $(\mathrm{Pb})$ to $150 \mathrm{ppm}$, Cadmium (Cd) 3 ppm, Arsenic (As) 13 ppm, Mercury (Hg) 0.8 ppm. (BSN 2004). Therefore, the content of heavy metals in liquid organic fertilizer produced is still below the threshold, moreover for heavy metal $\mathrm{Hg}$ is not detected (Table 1).

\section{CONCLUSION}

In the liquid organic fertilizer produced from dairy farm waste, Escherichia coli and Salmonella sp. were detected below the recommended limit as mentioned in Permentan number 70/Permentan/SR/140/10/201. The content of heavy metals $\mathrm{Pb}, \mathrm{Cd}$, and As were very low (trace), while $\mathrm{Hg}$ was not detected.

\section{ACKNOWLEDGEMENT}

In particular, the authors profoundly indebted to Direktorat Jenderal Pendidikan Tinggi Kementerian Ristek dan Pendidikan Tinggi, The Director of Research and Community Service Institute (DRPM) Universitas Padjadjaran who supported and made this study possible.

\section{REFERENCES}

Alloway BJ. 1995. Heavy metals in soils. Glasgow (UK): Blackie Academic and ProfessionalChapman \& Hall, Springer Science and Business Media.

Ashbolt NJ, Grabow WOK, Snozzi M. 2001. Indicators of Microbial Water Quality. In: Fewtrell L, Bartram J, editors. Water Quality: Guidelines, Standards and Health. WHO. London (UK): IWA Publ.

BSN. 2004. Standar kualitas pupuk organik. SNI 19-7030-2004. Jakarta (Indonesia): Badan Standardisasi Nasional.

Dalzell HW, Biddlestone AJ, Gray KR, Thurairajan K. 1987. Soil management: compost production and use in tropical and subtropical environments. Soil Bull. 56:22-27, 162.

Epstein E. 1997. The science of compostingtechnomic. Lancaster (USA): Lancaster Publishing Inc.

Feachem RG, Bradley DJ, Gerlick H, Mara DD. 1983. Sanitation and Desease: Health aspects of excreta and wastewater management. Word Bank Studies in Water Supply and Sanitation 3. Bath (UK): John Wiley and Sons, The Pitman Press.

Gray NF. 2008. Drinking water quality, problem and solutions. Second edition. Cambridge (UK): Cambridge University Press.

Jay J, Loessner MJ, Golden DA. 2005. Modern food microbiology. 7th Ed. New York (USA): Springer.

Kementan. 2011. Permentan No. 70/Permentan/SR/140/10/2011 tentang Persyaratan Teknis Minimal Pupuk Cair Organik. Jakarta (Indonesia): Kementerian Pertanian. 
Lacatusu R, Lungu M, Teodorescu S, Burileanu MMS, Lacatusu AR, Stroe VM, Lazar R, Rizea N. 2011. Heavy metals abundance in the soils of the Pantelimon-Branesti Area, Ilfov County: Iron, Manganese, Nickel, Lead, Zinc. Present Env Sustain Dev. 5:195-20.

Laegreid M, Bockman OC, Kaarstad O. 1999. Agriculture, fertilizer and the environment. New York (USA): CABI Publishing in association with Norsk Hydro ASA.

Levine MM. 1987. J Infect Dis. Mar;155(3):377-89. Escherichia coli that cause diarrhea: enterotoxigenic, enteropathogenic, enteroinvasive, enterohemorrhagic, and enteroadherent.

Marlina ET, Hidayati YA, Harlia E. 2008. Pengaruh penambahan berbagai starter pada proses pengomposan limbah pasar tradisional terhadap penurunan jumlah bakteri total dan koliform. Dalam: Hayati A, Yanuriati A, Widowati TW, Agustina H, Hersyamsi, Pratama F, Triana AN, Puspitahati, penyunting. Prosiding Semnas dan Kongres PATPI. Palembang, 14-16 Oldober 2008. Palembang (Indonesia): Perhimpunan Ahli Teknologi Pangan Indonesia. p. 484-487.

Juanda W. 2010. Jumlah bakteri total dan enterobacteriaceae pada kompos campuran feses kuda dan feses sapi potong pada imbangan berbeda. J Penelitian Univ Jambi Seri Sains. 12:16-19.

Nordberg GF, Nordberg M. 1986. Biological monitoring of Cadmium. Department of Environmental Medicine. Umea (Sweden): Umea University.

Sterritt RM, Lester JH. 1988. Microbiology for environmental and public health engineers. London (UK): E \& FN Spoon Ltd. 278 p.

Benito AK Tb., Hidayati YA, Marlina ET. 2010. Pengaruh tinggi pengomposan feses sapi potong dan sampah organik terhadap jumlah bakteri dan koliform pada kompos. J Penelitian Univ Jambi Seri Sains. 12:4-7.

Pholprasert C. 1989. Organic waste recycling. Chichester (UK): John Wiley \& Son. 